\title{
CARTA DO RECIFE
}

Professores/as, estudantes, pesquisadores/as e gestores em educação e instituições educacionais presentes ao V Seminário Paulo Freire, em Recife, reafirmam a relevante contribuição de Paulo Freire para a construção de um projeto social e de educação, no horizonte da justiça social

\begin{abstract}
Reunidos no V Seminário Paulo Freire, promovido pela Cátedra Paulo Freire da Universidade Federal de Pernambuco, professores, estudantes, pesquisadores/as e gestores em educação e instituições educacionais
\end{abstract} expressaram seu repúdio ao posicionamento de manifestantes, nas mobilizações políticas de caráter conservador, que tiveram lugar no último dia 15 de março do corrente ano, na cidade de Brasília. Naquela ocasião conclamava-se, a contracorrente do que defendem as forças vivas da população brasileira, afeitas ao pensamento emancipador, um basta ao educador, Patrono da educação brasileira, Paulo Freire.

O repúdio foi expresso através de Carta Aberta, proposta pela Cátedra Paulo Freire da UFPE e pela Cátedra de EJA da UNESCO, Núcleo UFPE, aprovada por unanimidade dos presentes ao Seminário, no dia 08 de maio, passando a chamar-se Carta do Recife.

Participantes do V Seminário Paulo Freire, diante do repúdio, de grupos conservadores, ao pensamento e a proposta político pedagógica de Paulo Freire, ocorrido nas manifestações de 15 de março do corrente ano, vem a público expressar o seu reconhecimento para a luta histórica, deste educador brasileiro, pela justiça social através da educação, ao seu compromisso com um projeto de sociedade e de educação que tenha como horizonte os direitos humanos e sociais e a relevância dos seus referenciais na construção de uma pedagogia crítico-transformadora.

Professores/as, instituições e entidades de classe que constituem movimentos sociais progressistas, assim como a produção acadêmica nacional e internacional, têm mostrado a universalidade da contribuição freireana para diversos setores e segmentos da sociedade e a relevância política, pedagógica e social do seu pensamento. Nessa perspectiva, temos afirmado que Paulo Freire é 
um pensamento vivo, vigoroso, atual, sem fronteiras, assim como é referencial para se pensar políticas públicas e práticas sociais e educacionais no horizonte dos direitos humanos e da justiça social. Contraditoriamente, a atualidade, o vigor e a contribuição política e pedagógica de Paulo Freire inquietam a grupos conservadores, que passaram a destilar ódio em diferentes contextos políticos e institucionais. Esse ódio insano se fez voz de repúdio a Paulo Freire, nos acontecimentos de 15 de março.

Por que tamanho ódio a um educador que, com suas ideias e o trabalho individual e coletivo, lutou pelos direitos humanos e por justiça social? Por que o rechaço a um cidadão brasileiro, e do mundo, que deixou como legado uma filosofia e pedagogia que têm como horizonte a humanização do humano? Por que conclamar a um basta ao educador que defendeu, com seu incansável trabalho na educação, a condição humana das gentes oprimidas, excluídas, invisíveis e assujeitadas?

Paulo Freire, Patrono da Educação Brasileira, formulou e praticou uma educação através da qual homens e mulheres se reconhecem e são reconhecidos como sujeitos do conhecimento e da história, não importando sua condição sócioeconômico-cultural ou seu território de vida e de trabalho. Formulou e praticou uma educação problematizadora que se realizou através de temas/questões que emergiam da realidade social, dos contextos de vida e das vivências de homens e mulheres, constituídos conteúdos da educação, os quais, quando problematizados, possibilitaram reflexão, apropriação crítica da realidade e ação transformadora.

Embora, inicialmente, suas ideias e práticas tenham emergido como processos de alfabetização, era uma filosofia em ação que ganhava corpo e se experimentava no final dos anos 1950/1960 em diversos pontos do país (Recife, Angicos, Brasília). A experiência que despontava no Nordeste do Brasil, e que logo se espalhou pelo mundo, incomodou segmentos que haviam se apossado da direção política do país. Como registra a história recente, essa educação emergente e diferenciada foi interrompida no Brasil, uma vez que ameaçava o poder político e econômico constituído e arrancava do homem e da mulher 
brasileiros/as a sua condição de protagonistas das suas próprias vidas - vivências - e História.

A educação proposta e vivenciada por Paulo Freire reconhecia a vocação ontológica de ser mais do homem e da mulher, e, por reconhecê-la, respondia com processos de produção do conhecimento e não com processos de transferência daquele e daquela que sabem mais para aquele e aquela que sabem menos ou que não sabem. Essa prática educacional foi interrompida com o golpe de 1964, mas não foi anulada.

O autoritarismo no poder, o golpe de estado, interrompeu a experiência no chão brasileiro, mas não o sonho coletivo, também sonhado por Freire que, apesar das adversidades, deu continuidade ao trabalho; permaneceu na luta e na construção da pedagogia da humanização fora do Brasil, mas sem se distanciar dele.

Foi esse o "crime" que Paulo Freire cometeu - promover uma educação conscientizadora. Contribuir para o empoderamento de homens e mulheres através da educação. Criar as condições de visibilidade do homem e da mulher enquanto seres silenciados, marginalizados e coisificados.

O "crime" deste pedagogo foi ter afirmado, com a prática, que a educação é um ato político; foi ter honrado a opção política de colocar a educação a serviço da humanização, da libertação, da justiça e do direito. Foi essa pedagogia da leitura crítica e da intervenção na realidade que perspectivava um projeto de sociedade democrática que lhe valeu a prisão, o exílio, a perda dos direitos políticos em seu país. Mas, estávamos nos anos de 1960, era plena ditadura militar. E hoje?

O processo de redemocratização do país trouxe Paulo Freire de volta, entre outros e outras exilados/as. Voltou com seu sonho (e de muitos de nós) de justiça e com experiências consolidadas na andarilhagem por culturas diversas e desafios políticos. No tempo de exílio, respondeu aos convites com suas contribuições teórico-epistemológicas tecidas no Brasil, coerente com a opção política de colocar a educação como prática da liberdade, não se afastando do sonho que fazia da educação uma prática local que podia passar a ser planetária. 
Paulo Freire é esse educador brasileiro, ao mesmo tempo recifense e cidadão do mundo; andarilho da utopia, que sem mágoa e sem medo (sabemos todos/as que com ele convivemos) lutou esperançoso pelo estado de direito, por uma sociedade justa e igualitária, pela condição de sujeito e de dignidade do homem e da mulher.

PAULO FREIRE É UM TESTEMUNHO DE DIÁLOGO entre culturas, de um pensar crítico esperançoso que fez da educação um dos instrumentos de luta e de construção social e que deposita sempre sua esperança na busca, cujo pensamento se constitui num paradigma para a educação no século XXI.

PAULO FREIRE É UMA PEDAGOGIA que tem como horizonte a construção de uma nova humanidade, uma educação libertadora e humanizadora, a qual estamos a carecer no século XXI no planeta Terra, e no Brasil em particular. Uma educação que, mais do que evidenciar, se comprometa com a superação de práticas minimizadoras, focalistas, exploradoras, preconceituosas e negadoras do ser mais.

PAULO FREIRE É UM COMPROMISSO SOCIAL E ÉTICO UNIVERSAL que somente aqueles/aquelas que colocam o direito e a justiça social como horizonte das políticas públicas, dos projetos e das ações podem optar. Por isso, Paulo Freire é uma opção política. Portanto, não é, nem esperamos que seja, pensamento consensual, nem opção universal. Não é, nem será, opção de alas e grupos conservadores, defensores de privilégios. Mas é e continuará sendo referencial para aqueles e aquelas que lutam por justiça social.

Recife, 08 de maio de 2015. 